\title{
Ontogeny, distribution and potential roles of 5 -hydroxymethylcytosine in human liver function
}

\author{
Maxim Ivanov ${ }^{1 *}$, Mart Kals ${ }^{2 \dagger}$, Marina Kacevska ${ }^{1 \dagger}$, Isabel Barragan ${ }^{1}$, Kie Kasuga ${ }^{3}$, Anders Rane ${ }^{4}$, Andres Metspalu ${ }^{2,5,6}$, \\ Lili Milani ${ }^{2,6+}$ and Magnus Ingelman-Sundberg ${ }^{1 \dagger}$
}

\begin{abstract}
Background: Interindividual differences in liver functions such as protein synthesis, lipid and carbohydrate metabolism and drug metabolism are influenced by epigenetic factors. The role of the epigenetic machinery in such processes has, however, been barely investigated. 5-hydroxymethylcytosine $(5 \mathrm{hmC})$ is a recently re-discovered epigenetic DNA modification that plays an important role in the control of gene expression.
\end{abstract}

Results: In this study, we investigate $5 \mathrm{hmC}$ occurrence and genomic distribution in 8 fetal and 7 adult human liver samples in relation to ontogeny and function. LC-MS analysis shows that in the adult liver samples $5 \mathrm{hmC}$ comprises up to $1 \%$ of the total cytosine content, whereas in all fetal livers it is below $0.125 \%$.

Immunohistostaining of liver sections with a polyclonal anti-5hmC antibody shows that $5 \mathrm{hmC}$ is detected in most of the hepatocytes. Genome-wide mapping of the distribution of $5 \mathrm{hmC}$ in human liver samples by next-generation sequencing shows significant differences between fetal and adult livers. In adult livers, $5 \mathrm{hmC}$ occupancy is

overrepresented in genes involved in active catabolic and metabolic processes, whereas $5 \mathrm{hmC}$ elements which are found in genes exclusively in fetal livers and disappear in the adult state, are more specific to pathways for differentiation and development.

Conclusions: Our findings suggest that 5-hydroxymethylcytosine plays an important role in the development and function of the human liver and might be an important determinant for development of liver diseases as well as of the interindividual differences in drug metabolism and toxicity.

\section{Background}

There are substantial interindividual differences in many liver processes, including intermediary metabolism, protein synthesis, carbohydrate metabolism and the detoxification of drugs and other xenobiotics. With respect to variation in drug metabolism, transport and toxicity, much knowledge has been gained from studies investigating genetic factors responsible for interindividual differences. However, little is known regarding the role of epigenetic factors, such as DNA modifications and their influence on hepatic gene expression, function and interindividual variation [1].

The epigenetic DNA modifications include methylation and hydroxymethylation of cytosine. For many

\footnotetext{
* Correspondence: maxim.ivanov@ki.se

+ Contributed equally

'Section of Pharmacogenetics, Department of Physiology and Pharmacology, Karolinska Institutet, Nanna Svartz väg 2, 17177 Stockholm, Sweden
}

Full list of author information is available at the end of the article years, 5-methylcytosine $(5 \mathrm{mC})$ was believed to be the only epigenetic modification of genomic DNA, often referred to as 'the fifth base' of the genome. Recently, 5hydroxymethylcytosine $(5 \mathrm{hmC})$ was discovered as a novel epigenetic factor in mammalian DNA that can have a stable effect on gene transcription and has hence been regarded as 'the sixth base' of the genome $[2,3]$. $5 \mathrm{hmC}$ originates from an enzymatic oxidation of $5 \mathrm{mC}$ by TET1, TET2 and TET3 proteins $[2,4]$, which recognize their substrate $5 \mathrm{mC}$ by the amino-terminal CXXC zinc finger domain [5]. This reaction is dependent on $\mathrm{Fe}^{2+}$ as well as $\alpha$-ketoglutarate; the latter, in turn, is dependent on the activity of either isocitrate dehydrogenase IDH1 in the cytosol and peroxisomes or IDH2 and IDH3 in mitochondria [6,7]. Although other proteins may also have some significance in establishing the presence of genomic $5 \mathrm{hmC}$, the TET and IDH proteins seem to play a very important role as determinants of the global $5 \mathrm{hmC}$ content.

\section{C) Biomed Central}


Hydroxymethylcytosine can serve as an intermediate of active DNA demethylation if further oxidized by TET enzymes to 5-formylcytosine ( $5 \mathrm{fC})$ and then to 5 -carboxylcytosine $(5 \mathrm{caC})$, which in turn is removed by thymine-DNA glycosylase. The resulting abasic site is repaired by the base excision repair mechanism, producing unmethylated cytosine $[8,9]$. The level of $5 \mathrm{fC}$ was found to be extremely low in mouse embryonic stem cells and brain cortex (0.02 to $0.002 \%$ from total cytosine) $[9,10]$. Despite the recent progress in genome-wide mapping of $5 \mathrm{fC}$ in mouse embryonic stem cells, there is still no convincing evidence for its role as an epigenetic modification [11,12]. In contrast, $5 \mathrm{hmC}$ is 10 to 100 times more abundant than $5 \mathrm{fC}$ and can stably persist in vivo, thus serving as an epigenetic mark with unique regulatory functions.

Several functional differences have been demonstrated between the two DNA modifications $5 \mathrm{mC}$ and $5 \mathrm{hmC}$. Firstly, the vast majority of $\mathrm{CpG}$ sites throughout the genome (except for those located in $\mathrm{CpG}$ islands and shores) are constantly methylated. In contrast, $5 \mathrm{hmC}$ can be found at only a relatively small subset of CpG sites. Furthermore, variable methylation correlating with gene expression has been described mostly in the promoter regions, whereas the genomic distribution of $5 \mathrm{hmC}$ is biased towards exonic regions. In addition, $5 \mathrm{mC}$ is, in most cases, a repressive epigenetic mark, whereas the presence of $5 \mathrm{hmC}$ correlates with active gene transcription [13-21]. The latter observation can be explained by the different affinity of $5 \mathrm{mC}$ and $5 \mathrm{hmC}$ for methylated DNA binding proteins. It was demonstrated that MeCP1, MBD1, MBD2 and MBD4 bind to methylated but not to hydroxymethylated loci [22,23], whereas MBD3 binds to $5 \mathrm{hmC}$ with even higher affinity than it does to $5 \mathrm{mC}$ [24]. Moreover, the composition of DNA binding and histone modifying proteins in $5 \mathrm{hmC}$-containing loci can also be very different from that of methylated DNA, thus resulting in different gene expression outcomes [16,18-20,25].

Highly variable levels of $5 \mathrm{hmC}$ have been detected in many human and mammalian tissues and cell types with characteristic tissue-specific patterns [14]. $5 \mathrm{hmC}$ is especially enriched in brain tissue and in embryonic stem cells, where it constitutes up to 1 to $1.3 \%$ of the total cytosine content $[14,17,26-29]$. Furthermore, $5 \mathrm{hmC}$ has been shown to participate in neurodevelopment and has been associated with pluripotent cell states [30-32]. In cancers, such as prostate, breast, melanoma, glioma and colon carcinoma, the content of $5 \mathrm{hmC}$ is significantly decreased compared to normal tissue, is usually associated with decreased TET or IDH expression and, more importantly, can affect the tumor phenotype $[7,14,33,34]$. With respect to human liver, very little is known about $5 \mathrm{hmC}$ distribution and function.
In this study we demonstrate that adult human livers contain high levels of $5 \mathrm{hmC}$, which are comparable to those found in the brain tissue. The analysis of genomewide $5 \mathrm{hmC}$ hepatic distribution revealed that $5 \mathrm{hmC}$ is particularly enriched in coding regions of actively transcribed genes. In addition, the results show profound differences in both genomic distribution and global $5 \mathrm{hmC}$ content between fetal and adult liver samples. These differences were further pronounced by pathway analysis of genes enriched for $5 \mathrm{hmC}$ elements, which clearly showed consistency with liver development, thus suggesting that $5 \mathrm{hmC}$ may play an important role in hepatic development and function.

\section{Results}

\section{Global $5 \mathrm{mC}$ and $5 \mathrm{hmC}$ content in fetal and adult human} livers

Global levels of $5 \mathrm{mC}$ and $5 \mathrm{hmC}$ were determined in eight fetal and seven adult human livers using liquid chromatography-mass spectrometry (LC-MS) analysis, based on calibration curves with known $5 \mathrm{mC}$ and $5 \mathrm{hmC}$ content. The quantification range of $5 \mathrm{hmC}$ was from 0.0625 to $1.0 \%$ of total cytosine, suggesting our method is highly sensitive. The linear standard curve has excellent fit $\left(\mathrm{R}^{2}>\right.$ 0.999; Figure $\mathrm{S} 1$ in Additional file 1). Therefore, we used this calibration curve to determine global levels of $5 \mathrm{mC}$ and $5 \mathrm{hmC}$ in eight fetal and seven adult human livers. The $5 \mathrm{mC}$ and $5 \mathrm{hmC}$ contents of fetal and adult samples are shown in Figure 1 (for details, see Table S2 in Additional file 1). The median $5 \mathrm{mC}$ content was $4.2 \%$ of total cytosine in fetal livers and $5.3 \%$ in adult livers. By contrast, much less $5 \mathrm{hmC}$ was found in fetal livers compared to adult livers (Figure 1). All eight fetal samples had a $5 \mathrm{hmC}$ content lower than $0.125 \%$, whereas the signal from six out of seven adult samples was above $0.2 \%$, and the median $5 \mathrm{hmC}$ content for adults was $0.62 \%$ of total cytosine.

\section{Immunohistostaining of human liver samples}

In order to explore the distribution of $5 \mathrm{hmC}$ in the liver, we immunostained human liver sections for both this cytosine modification as well as for $5 \mathrm{mC}$. As depicted in Figure 2, both $5 \mathrm{mC}$ and $5 \mathrm{hmC}$ were detected in the nuclei of most hepatocytes within the liver tissue sections. No significant difference regarding intranuclear localization between $5 \mathrm{mC}$ and $5 \mathrm{hmC}$ was observed. Threedimensional analysis of the sections further revealed the abundant distribution of $5 \mathrm{hmC}$ to the majority of hepatocytes (data not shown).

\section{Quantification of TET1-3 and IDH1-2 transcripts}

The observed differences in global $5 \mathrm{hmC}$ content between fetal and adult cohorts may be explained by 


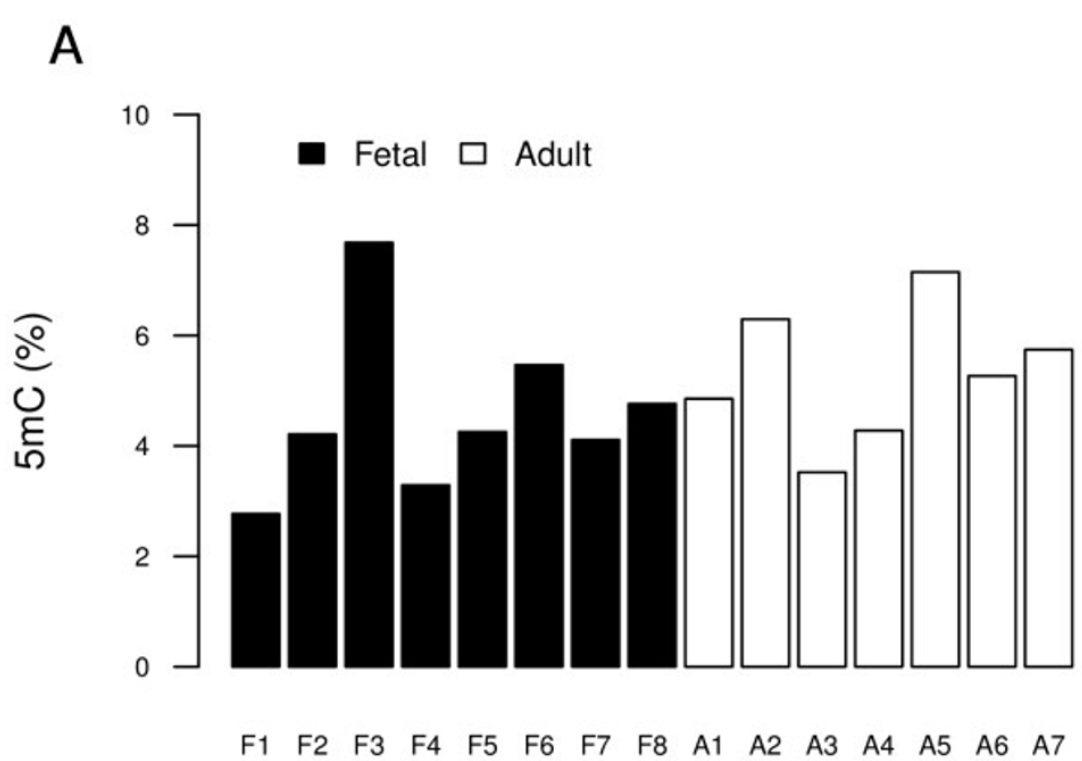

B

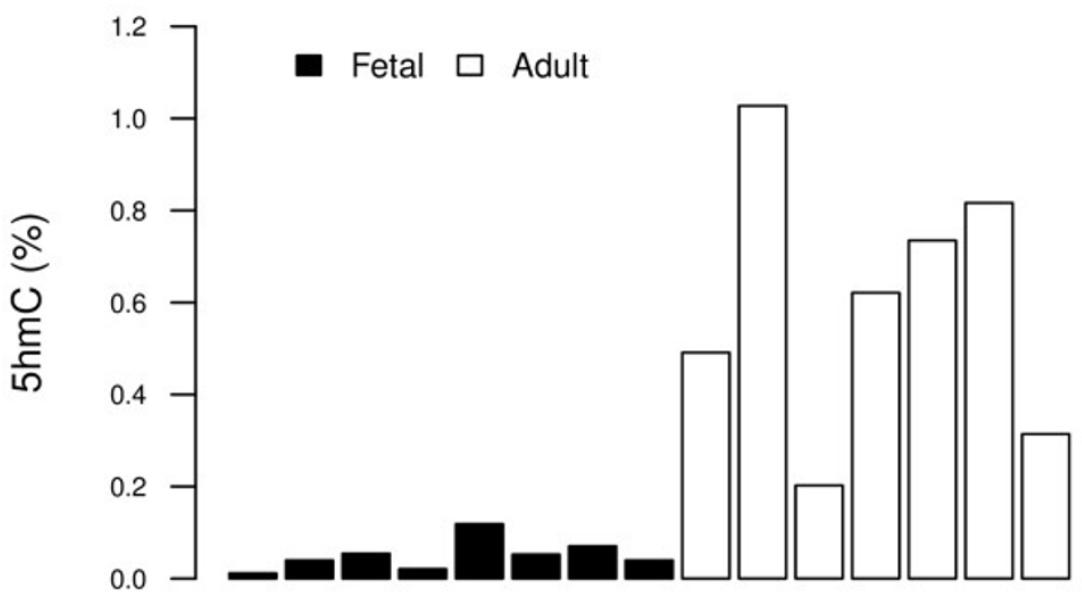

$\begin{array}{lllllllllllllll}\text { F1 } & \text { F2 } & \text { F3 } & \text { F4 } & \text { F5 } & \text { F6 } & \text { F7 } & \text { F8 } & \text { A1 } & \text { A2 } & \text { A3 } & \text { A4 } & \text { A5 } & \text { A6 } & \text { A7 }\end{array}$

Figure 1 Total $5 \mathrm{mC}$ and $5 \mathrm{hmC}$ in fetal and adult livers as determined by LC-MS. The percentage of (a) $5 \mathrm{mC}$ and (b) $5 \mathrm{hmC}$ in relation to the total cytosine content in eight fetal and seven adult livers is shown.

differences in expression of the TET and/or IDH enzymes, which are involved in the conversion of $5 \mathrm{mC}$ to $5 \mathrm{hmC}$. The mRNA levels of TET1-3 and IDH1-2 were assessed by quantitative RT-PCR in 14 fetal and 33 adult livers, including the samples investigated by LC-MS. Interestingly, the results showed a significant decrease in all TET genes $(P<0.0001)$ in adult livers when compared to fetal (Figure 3). However, the slight increase in IDH1 $(P=0.0024)$ and IDH2 $(P<0.0001)$ in adult samples may potentially explain the higher total $5 \mathrm{hmC}$ content in these livers compared to fetal $5 \mathrm{hmC}$ levels.

\section{Genome-wide profiling of $5 \mathrm{hmC}$}

To investigate the genome-wide distribution of $5 \mathrm{hmC}$, we enriched the $5 \mathrm{hmC}$-containing fraction of the DNA samples from the eight fetal and seven adult human livers. Both $5 \mathrm{hmC}$-enriched DNA samples and their non-enriched counterparts were ligated with adapters, amplified and then subjected to next-generation sequencing (NGS), as described in Materials and methods. The main quality metrics of the NGS experiment as well as the number of called $5 \mathrm{hmC}$ peaks for each liver sample are listed in Table S3 in Additional file 1. 


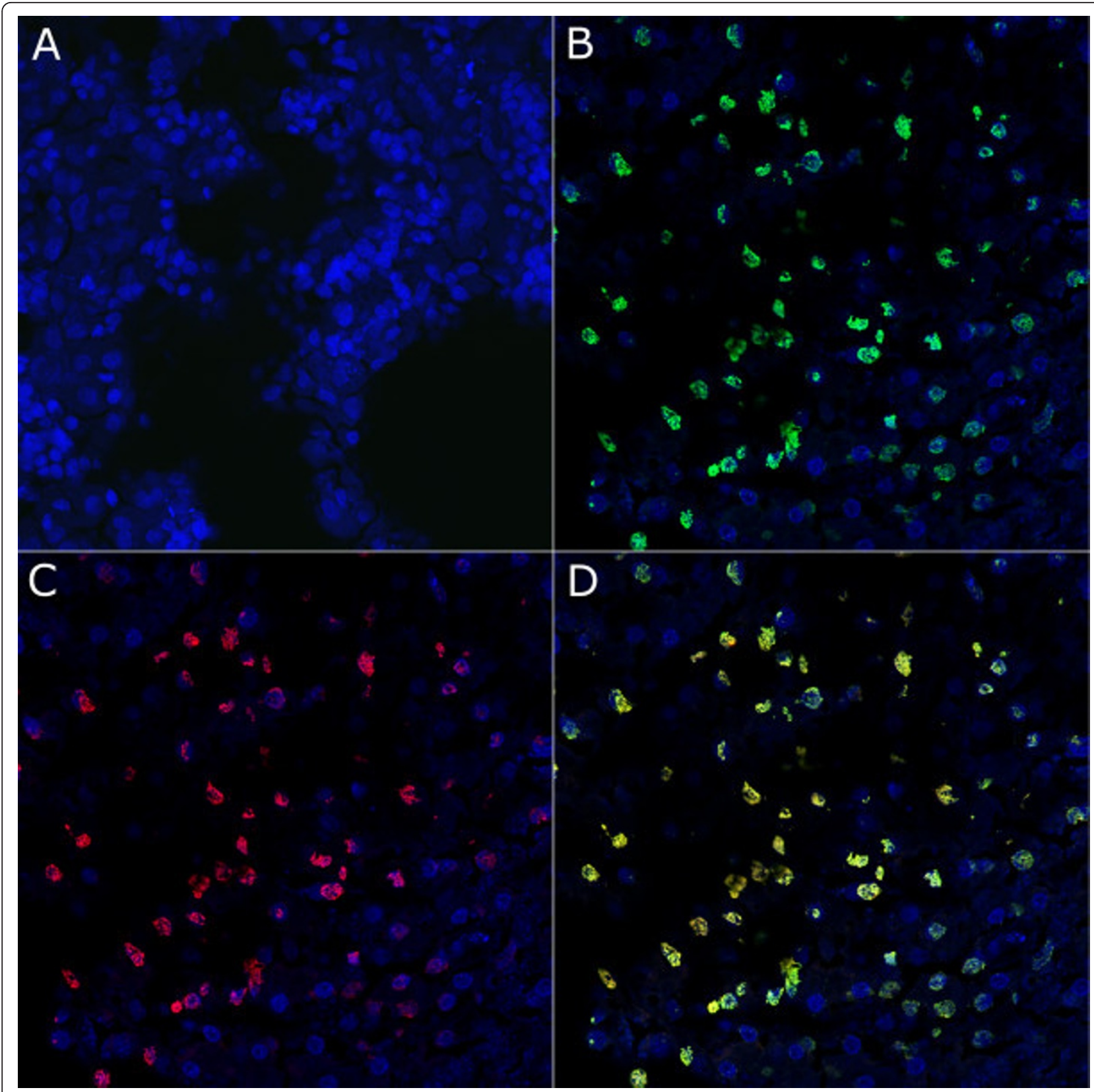

Figure 2 Immunostaining of human adult liver for $\mathbf{5 m C}$ and $\mathbf{5 h m C}$. Representative stainings of $40 \mu \mathrm{M}$ adult liver sections are shown. (a) Negative control without the primary antibody. (b) Staining with the monoclonal antibody to $5 \mathrm{mC}$ (green) and DAPI (blue). (c) Staining with a polyclonal antibody against $5 \mathrm{hmC}$ (red) and DAPI (blue). (d) Merge of $5 \mathrm{mC}$ and $5 \mathrm{hmC}$ staining and DAPI. As evident from (d), $5 \mathrm{mC}$ and $5 \mathrm{hmC}$ show similar patterns of intranuclear distribution, indicating that $5 \mathrm{hmC}$, when present, tends to co-localize with $5 \mathrm{mC}$ in the hepatocyte nucleus.

Overall, the fetal liver samples showed significantly fewer $5 \mathrm{hmC}$ peaks $(11,366$ to 32,522$)$ covering a smaller portion of the genome (10 to $40 \mathrm{Mb}$ ) compared to adult samples $(68,779$ to 134,956 peaks covering 80 to 203 $\mathrm{Mb})$. These results are in agreement with the finding by LC-MS that global $5 \mathrm{hmC}$ content is lower in fetal livers than in adults. Furthermore, the $5 \mathrm{hmC}$ peaks appear to be unevenly distributed among chromosomes, being over-represented on chromosomes 16, 17, 19 and 22 and under-represented on the sex chromosomes (Figure S2 in Additional file 1).

When investigating the proportion of peaks that were shared by samples belonging to each cohort, a small fraction of peaks was shared by all fetal samples $(2.5 \%)$ and all adult samples (8.3\%; Figure S3 in Additional file 1). A large majority of the peaks were identified as unique 


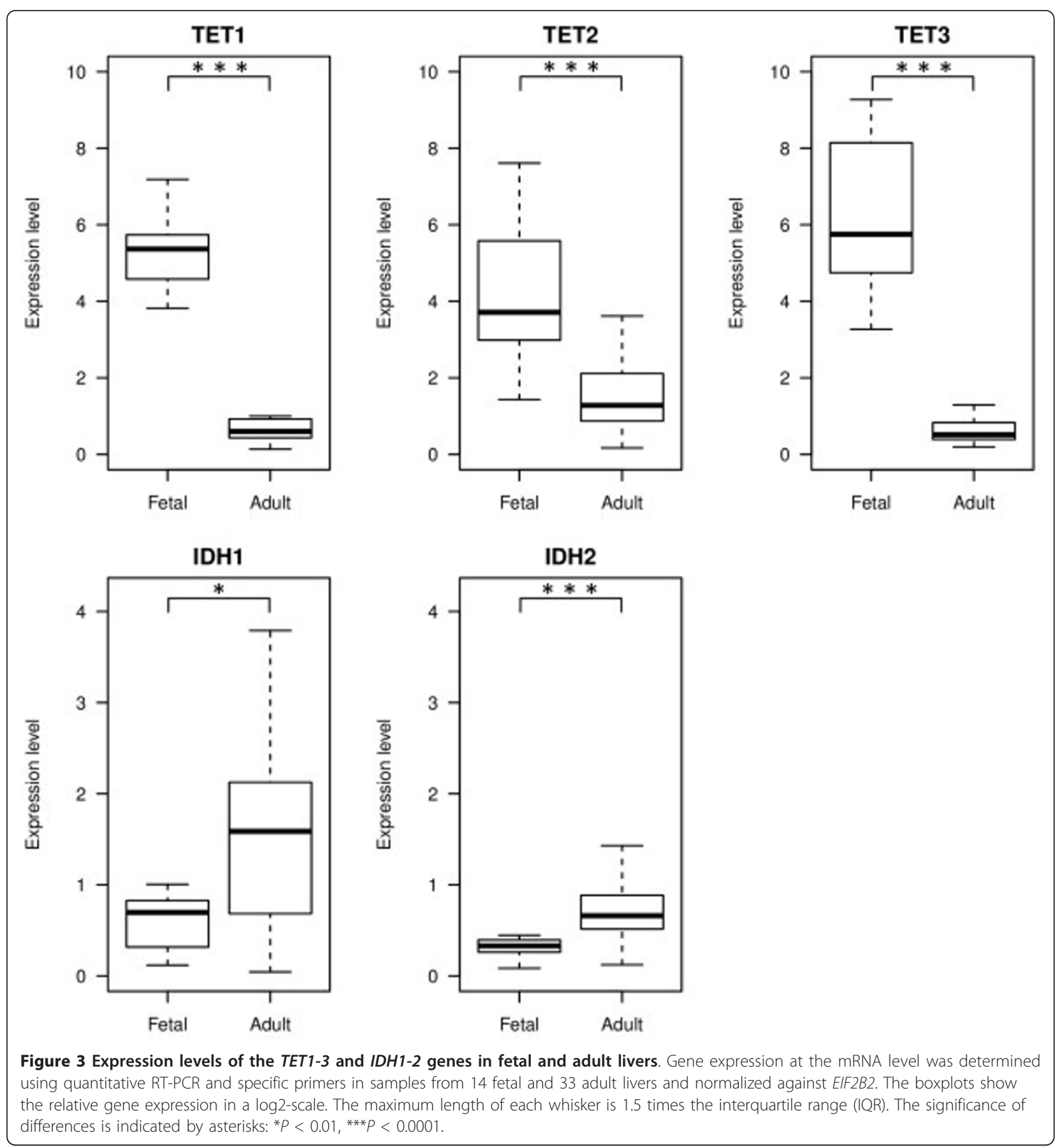

peaks $(54.4 \%$ in fetal and $36.1 \%$ in adult livers), suggesting high interindividual variability in the genomic distribution of $5 \mathrm{hmC}$. On the other hand, a significant proportion of hydroxymethylation reproducibly appears at the same genomic locations, as seen when comparing $5 \mathrm{hmC}$ peaks shared by more than one sample. Examples of the distribution of $5 \mathrm{hmC}$ peaks in five different genes are shown in Figure 4. We focused on the continuous genomic intervals, or ' $5 \mathrm{hmC}$ blocks', where $5 \mathrm{hmC}$ occupancy was detected in at least two samples in a given cohort (Figure 4a). In other words, '5hmC blocks' represent genomic intervals that are prone to be hydroxymethylated in a given cohort (although not necessarily hydroxymethylated in every sample in this cohort). In contrast, the probability to detect $5 \mathrm{hmC}$ outside of $5 \mathrm{hmC}$ blocks is relatively low. Of the five genes illustrated in 
A

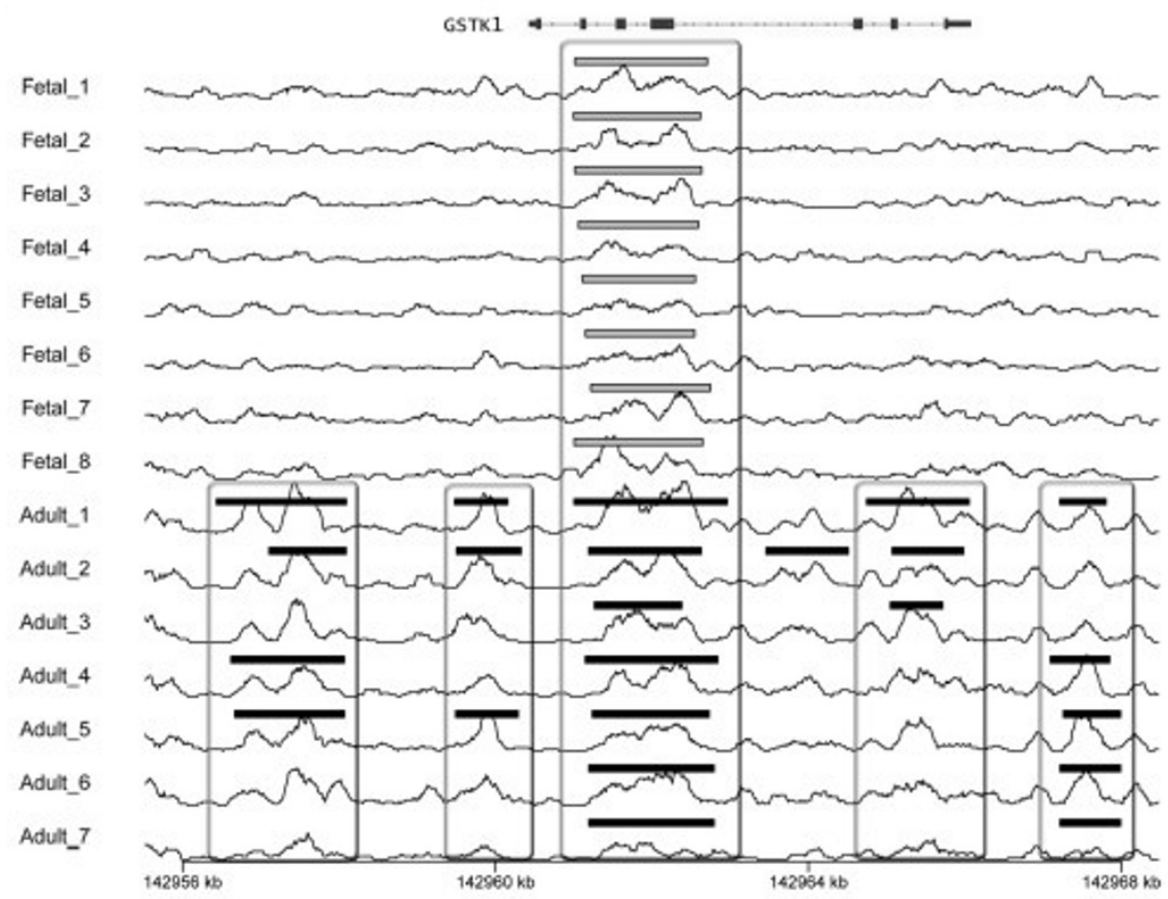

B
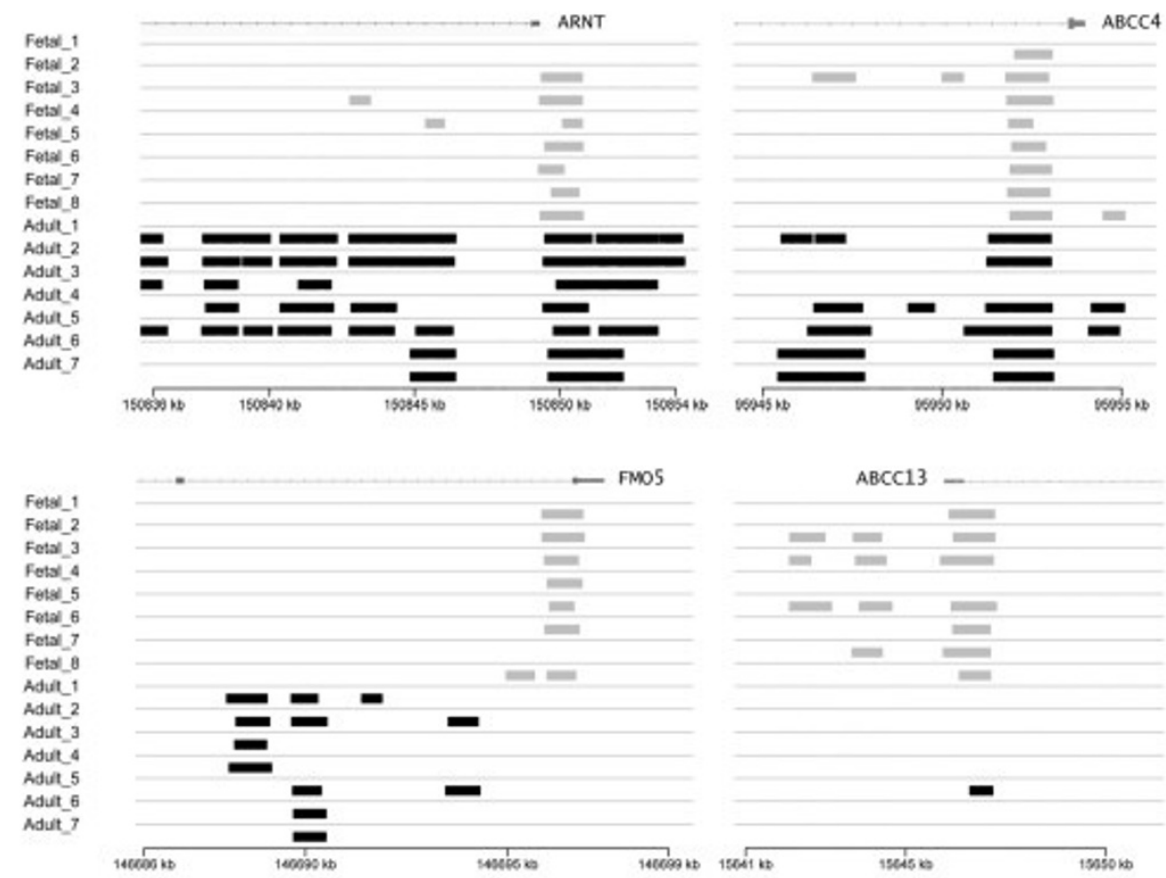

Figure 4 The distribution of $5 \mathrm{hmC}$ peaks in five liver genes. (a) A detailed view of the GSTK1 gene. For each 5hmC-enriched sample (y-axis), the read depth is plotted against the genomic coordinates in the given interval ( $\mathrm{x}$-axis). The $5 \mathrm{hmC}$ peaks called by the MACS software are shown by the short horizontal lines. The $5 \mathrm{hmC}$ blocks identified in this study are denoted by vertical rectangles. (b) Representative illustration of the genomic positions of $5 \mathrm{hmC}$ peaks identified in the genes ARNT, ABCC4, FMO5 and ABCC13. The fetal peaks are shown in gray and the adult peaks are shown in black. 
Figure 4 , most had many more $5 \mathrm{hmC}$ blocks in adult livers, whereas in the $A B C C 13$ gene, $5 \mathrm{hmC}$ blocks were mainly identified in fetal livers. The relation between this variability and the differences in gene expression between the livers has to await analyses in larger cohorts. The full lists of fetal $(n=29,917)$ and adult $5 \mathrm{hmC}$ blocks $(n=116,911)$ identified in this study are available in Additional files 2 and 3, respectively.

\section{Locus-specific validation of next-generation sequencing data}

To validate our NGS data, we profiled $5 \mathrm{mC}$ and $5 \mathrm{hmC}$ content at single-base resolution for two randomly selected genomic intervals in four fetal and four adult liver DNA samples. The first interval (containing four CpG sites overlapping with a fetal-only $5 \mathrm{hmC}$ block) was located in intron 15 of the DROSHA gene, whereas the second one (containing seven CpG sites) was located in intron 2 of the $\mathrm{CDH} 2$ gene and manifested adult-only hydroxymethylation. The results of the single-base analysis are shown in Figure S5 in Additional file 1. The fetal hydroxymethylation in DROSHA (averaged over four CpG sites in each sample) could reach up to $35 \%$, whereas in adult samples it did not exceed $4 \%$. In contrast, fetal hydroxymethylation in $\mathrm{CDH} 2$ (averaged over seven CpG sites) was never higher than $5 \%$, whereas in adult samples it varied between 49 and 56\%. Thus, despite the single false positive and false negative $5 \mathrm{hmC}$ peaks identified for both genes, the $5 \mathrm{hmC}$ values obtained from the validation experiment are in good agreement with the NGS data.

\section{Genomic and functional localization of $5 \mathrm{hmC}$}

Next, we investigated the possible enrichment of $5 \mathrm{hmC}$ blocks in RefSeq genes, microRNA (miRNA) and long non-coding RNA (lncRNA) genes, hepatic enhancers, CpG islands (CGIs), CGI shores and repetitive sequences. We found that both fetal and adult $5 \mathrm{hmC}$ blocks are slightly enriched in RefSeq genes and strongly enriched in enhancers, miRNA genes, CGIs and CGI shores, but under-represented in IncRNA genes and repetitive regions (Figure $5 \mathrm{a}$ ). Furthermore, the relative enrichment of $5 \mathrm{hmC}$ blocks in enhancers, miRNA genes, CGIs and CGI shores is approximately double in fetal samples compared to adults, whereas in RefSeq genes and lncRNA genes as well as in repetitive regions the rate of $5 \mathrm{hmC}$ enrichment remains nearly constant during liver development.

To investigate if cytosine hydroxymethylation in human liver correlates with active gene transcription, we analyzed how $5 \mathrm{hmC}$ blocks are distributed among genes with different expression levels. To this end, we quantified the genome-wide mRNA expression levels of 14 fetal and 86 adult liver samples (including all samples employed in the NGS study). The analyzed 17,771 RefSeq genes were divided into low, intermediate and highly expressed genes, separately for fetal and adult cohorts. The relative enrichment of $5 \mathrm{hmC}$ blocks in each of these three categories of genes is shown in Figure $5 \mathrm{~b}$. Both fetal and adult $5 \mathrm{hmC}$ blocks are underrepresented in the genes with low expression or silent genes, and over-represented in genes with intermediate or high expression, suggesting a likely role for hydroxymethylation in active gene transcription.

\section{5hmC localization during development}

The observed profound differences in both global $5 \mathrm{hmC}$ content and the number of called $5 \mathrm{hmC}$ peaks between the fetal and adult liver samples suggest that $5 \mathrm{hmC}$ distribution is significantly modified during liver development throughout the genome. When comparing the fetal and adult hydroxymethylomes, we found 5,038 $5 \mathrm{hmC}$ blocks present in fetal livers only and 96,097 blocks detectable only in adult samples. These fetal- and adult-specific $5 \mathrm{hmC}$ blocks were then investigated for their distribution among the following five gene groups: I) fetal-specific genes (expressed in fetal samples, but silent in adults; $n=464)$; II) genes expressed in fetal samples at least two-fold higher than in adults $(n=$ $805)$; III) non-developmentally expressed genes ( $n=$ $8,731)$; IV) genes expressed in adult samples at least two-fold higher than in fetal samples $(n=1,079)$; and V) adult-specific genes (expressed in adult cohort, but silent in fetal cohort; $n=306)$. Relative enrichment values of genic fetal-specific and adult-specific $5 \mathrm{hmC}$ blocks in these groups of genes are shown in Figure 5c. As evident from these data, fetal-specific $5 \mathrm{hmC}$ blocks were seen strongly enriched in fetal expressed genes (groups I and II) but not in non-developmental (group III) or adult-specific genes (groups IV and V). Accordingly, adult-only $5 \mathrm{hmC}$ blocks are strongly under-represented in fetal-only genes (group I), but skewed towards genes that are exclusively expressed in the adult livers (groups IV and V). Hence, developmental patterns of hydroxymethylation correlate with developmental patterns of gene transcription in human livers.

\section{5-Hydroxymethylation in relation to gene function}

Finally, genes intersecting with fetal-only or adult-only $5 \mathrm{hmC}$ blocks were annotated to specific biological pathways using the GREAT software. Those genes that acquired hydroxymethylation in the adult state were found to be involved in active catabolic and metabolic processes, such as mRNA catabolic process, carbohydrate transport, fatty acid oxidation and lipid oxidation, which is well in line with the function of the adult liver. Meanwhile, the genes containing fetal-only $5 \mathrm{hmC}$ blocks were more specific to pathways for differentiation and 


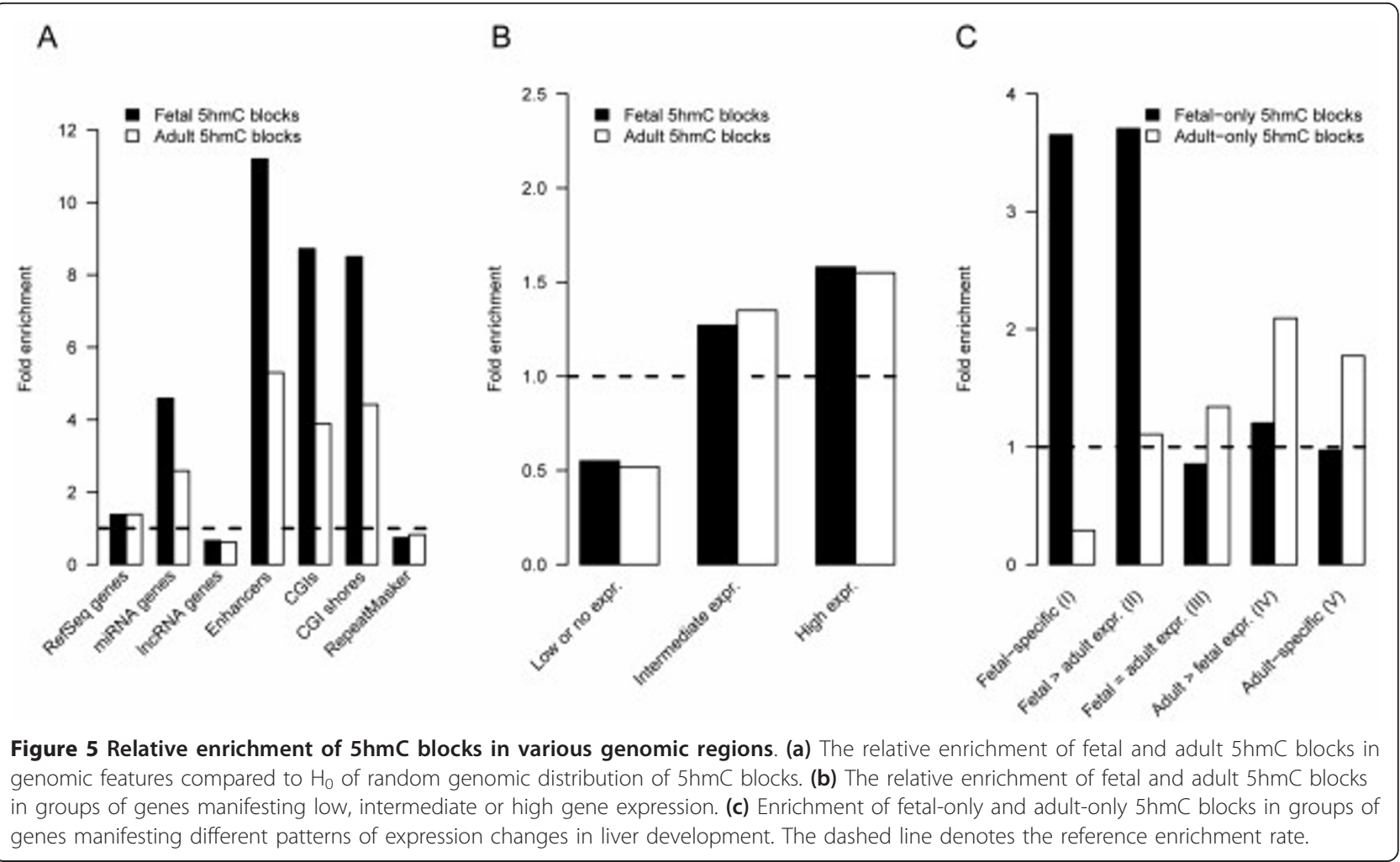

development, such as regulation of cell differentiation, stem cell development, and establishment or maintenance of cell polarity. The top 10 biological processes for these two groups of genes are given in Table 1.

\section{The comparison of human hepatic and cerebellum} hydroxymethylomes

We compared our data on fetal and adult hepatic hydroxymethylomes with the previously published $5 \mathrm{hmC}$ map of the human adult cerebellum [30]. The study of Szulwach and colleagues [30] revealed 43,272 5hmC-containing genomic intervals in the cerebellum, covering 15.1 Mb. Among them, 8.4 Mb (56\%) do intersect with the $5 \mathrm{hmC}$ blocks in adult liver. In addition, $3.3 \mathrm{Mb}$ of $5 \mathrm{hmC}$-containing sequences are shared between cerebellum and fetal liver, and 2.7 $\mathrm{Mb}$ are common for all these three tissues. Thus, these data indicate that, even though $5 \mathrm{hmC}$ distribution is tissue-specific, some $5 \mathrm{hmC}$ elements are conserved between different tissues and developmental stages. Pathway analysis of these conserved $5 \mathrm{hmC}$ elements reproducibly identified sterol metabolism and insulin response genes among the top 10 pathways (Table S4 in Additional file 1).

\section{Discussion}

Our study reports, for the first time, the characteristics of the $5 \mathrm{hmC}$ epigenetic modification in fetal and adult human livers. We have quantified the global $5 \mathrm{hmC}$ content in fetal and adult human livers by LC-MS and showed significantly higher levels of $5 \mathrm{hmC}$ in adult compared to fetal samples, accompanied by a correspondingly higher expression of $I D H$ genes, known $5 \mathrm{hmC}$ regulators. Our investigations of the global genomic distribution patterns of $5 \mathrm{hmC}$ using NGS categorize this DNA modification as an important mark in hepatic gene expression and development.

Until recently, quantification of $5 \mathrm{hmC}$ relied on less precise methods, mainly antibody detection techniques, and utilized a very small sample size. For example, Li and Liu [35] reported the $5 \mathrm{hmC}$ human liver content to be $0.45 \%$ of total DNA ( $0.09 \%$ of total cytosine), whereas Nestor et al. [14] reported values of approximately $0.22 \%$ of total cytosines. LC-MS enables sensitive and reliable quantification of $5 \mathrm{hmC}$. Previous studies in murine livers found that $5 \mathrm{hmC}$ content quantified by LC-MS was very low ( 0.05 to $0.07 \%$ from the total cytosine) compared to other murine tissues (for example, 0.3 to $0.7 \%$ in the central nervous system [26]. Importantly, LC-MS quantification of $5 \mathrm{hmC}$ in human liver, to our knowledge, has not been carried out before. Utilizing LC-MS together with a protocol developed to detect both $5 \mathrm{mC}$ and $5 \mathrm{hmC}$ within the same tissue sample, we were able to quantify the $5 \mathrm{mC}$ and $5 \mathrm{hmC}$ content in seven adult and eight fetal livers. In contrast to the data reported in mice, our results demonstrate that 
Table 1 Functional annotation of developmentally hydroxymethylated regions

\begin{tabular}{|c|c|c|c|c|c|}
\hline \multirow[b]{2}{*}{ Biological process } & \multicolumn{3}{|c|}{ Binomial test } & \multicolumn{2}{|c|}{ Hypergeometric test } \\
\hline & Raw $P$-value ${ }^{a}$ & FDR Q-value ${ }^{\text {b }}$ & Fold enrichment $^{c}$ & FDR Q-value & Fold enrichment $^{\mathrm{e}}$ \\
\hline \multicolumn{6}{|l|}{ Genes enriched with adult-only $5 \mathrm{hmC}$ blocks } \\
\hline Nuclear-transcribed mRNA catabolic process & 4.30E-182 & $3.22 \mathrm{E}-180$ & 2.49 & 8.82E-03 & 1.16 \\
\hline mRNA catabolic process & $8.88 \mathrm{E}-165$ & $5.52 \mathrm{E}-163$ & 2.25 & 1.77E-02 & 1.14 \\
\hline Carbohydrate transport & $3.29 \mathrm{E}-125$ & $1.51 \mathrm{E}-123$ & 2.06 & 5.91E-03 & 1.15 \\
\hline Vesicle localization & $9.48 \mathrm{E}-113$ & 4.05E-111 & 2.20 & 3.73E-02 & 1.16 \\
\hline Fatty acid oxidation & $5.52 \mathrm{E}-102$ & $2.12 \mathrm{E}-100$ & 2.22 & 4.59E-03 & 1.20 \\
\hline Lipid oxidation & $1.44 \mathrm{E}-100$ & 5.39E-99 & 2.20 & 3.97E-03 & 1.20 \\
\hline mRNA 3'-end processing & $1.73 \mathrm{E}-98$ & $6.27 \mathrm{E}-97$ & 2.24 & $1.11 \mathrm{E}-02$ & 1.17 \\
\hline Monocarboxylic acid catabolic process & 1.35E-95 & 4.80E-94 & 2.21 & $5.31 \mathrm{E}-03$ & 1.20 \\
\hline RNA 3'-end processing & $2.92 \mathrm{E}-94$ & $1.02 \mathrm{E}-92$ & 2.07 & $2.13 \mathrm{E}-02$ & 1.15 \\
\hline Fatty acid catabolic process & 2.99E-90 & 9.99E-89 & 2.22 & 1.00E-02 & 1.20 \\
\hline \multicolumn{6}{|l|}{ Genes enriched with fetal-only $5 \mathrm{hmC}$ blocks } \\
\hline Regulation of granulocyte differentiation & $5.88 \mathrm{E}-23$ & $2.45 \mathrm{E}-20$ & 6.20 & $3.56 \mathrm{E}-02$ & 2.58 \\
\hline Regulation of myeloid cell differentiation & $9.74 \mathrm{E}-17$ & 1.67E-14 & 2.19 & $1.84 \mathrm{E}-03$ & 1.64 \\
\hline Induction of apoptosis by extracellular signals & $5.49 \mathrm{E}-15$ & $7.18 \mathrm{E}-13$ & 2.18 & $9.28 \mathrm{E}-03$ & 1.54 \\
\hline Positive regulation of steroid metabolic process & $1.76 \mathrm{E}-12$ & $1.61 \mathrm{E}-10$ & 3.87 & 9.82E-03 & 2.37 \\
\hline Stem cell development & $6.00 \mathrm{E}-12$ & 5.05E-10 & 2.09 & 4.16E-04 & 2.06 \\
\hline Establishment or maintenance of cell polarity & $9.26 \mathrm{E}-11$ & $6.14 \mathrm{E}-09$ & 2.02 & 1.97E-02 & 1.63 \\
\hline Regulation of protein binding & $6.32 \mathrm{E}-10$ & $3.38 \mathrm{E}-08$ & 2.03 & $2.36 \mathrm{E}-02$ & 1.64 \\
\hline Stem cell maintenance & $8.22 \mathrm{E}-10$ & 4.31E-08 & 2.00 & 9.44E-04 & 2.04 \\
\hline Somatic stem cell maintenance & $6.28 \mathrm{E}-09$ & $2.59 \mathrm{E}-07$ & 2.15 & $2.15 \mathrm{E}-02$ & 2.04 \\
\hline Negative regulation of lipoprotein particle clearance & 1.99E-07 & $6.11 \mathrm{E}-06$ & 6.52 & $3.08 \mathrm{E}-02$ & 3.73 \\
\hline
\end{tabular}

$5 \mathrm{hmC}$ levels in the majority of human adult livers (0.5 to $1 \% 5 \mathrm{hmC}$ ) remain comparable to those found in the cerebral cortex (1 to $1.3 \% 5 \mathrm{hmC}$ ), the most DNA-hydroxymethylated human tissue identified to date [14,29]. As adult human livers have notably higher global $5 \mathrm{hmC}$ content than murine ones, mice are unlikely to serve as relevant models for the human hepatic hydroxymethylome. Moreover, LC-MS quantification of multiple liver samples also demonstrated that the overall content of both $5 \mathrm{mC}$ and $5 \mathrm{hmC}$ is variable between the samples.

Interestingly, fetal samples showed a significantly lower $5 \mathrm{hmC}$ content and very similar levels of total $5 \mathrm{mC}$ when compared to adult livers. Drastic differences in $5 \mathrm{hmC}$ levels between adult and fetal livers can suggest that DNA hydroxymethylation is an important epigenetic phenomenon for liver development. The observed increase of global $5 \mathrm{hmC}$ content in adult compared to fetal livers is interesting because, in the majority of studies, a high $5 \mathrm{hmC}$ content has been associated with an embryonic or undifferentiated state of tissues or cells. For example, Ruzov and co-authors [32] report changes of $5 \mathrm{hmC}$ abundance in the development of mouse and postulate that $5 \mathrm{hmC}$ is enriched in embryonic context compared to adult tissues. Szwagierczak and colleagues [28] showed significantly more $5 \mathrm{hmC}$ in undifferentiated mouse embryonic stem cells than in corresponding embryoid bodies, where the decrease in $5 \mathrm{hmC}$ content during differentiation was attributed to decreased expression of TET1. In addition, reprogramming of differentiated cells into induced pluripotent stem cells activates TET enzymes and leads to accumulation of $5 \mathrm{hmC}$, where the link between $5 \mathrm{hmC}$ levels and development was explained by the presence of binding sites for pluripotency-associated transcription factors (OCT4, SOX2) in the promoter of TET1 [13,31]. In contrast to these studies, our data indicate a decrease in the extent of $5 \mathrm{hmC}$ modifications from the early embryonic stages to adult liver. Similarly, Hahn and colleagues [36] showed that $5 \mathrm{hmC}$ is more abundant in terminally differentiated neurons than in neural progenitor cells, thus suggesting that the global $5 \mathrm{hmC}$ content increases with terminal maturation in specific tissues.

Our studies revealed that the lower $5 \mathrm{hmC}$ content in the fetal livers was accompanied by lower expression of 
the $I D H 1$ and $I D H 2$ genes, known regulators of $5 \mathrm{hmC}$ level. Hence, it is tempting to speculate that the increase of $5 \mathrm{hmC}$ in adult samples is due to the developmental increase of IDH enzymes. However, we did not observe any correlation between the individual $5 \mathrm{hmC}$ content and the levels of either TET1-3 or IDH1-2 transcripts in individual livers (data not shown), indicating that other factors contribute to the global $5 \mathrm{hmC}$ content of human liver. Thus, we cannot completely rule out the possibility that the level of TET and/or IDH enzymes can be regulated in a post-transcriptional or post-translational manner, and the developmental burst of $5 \mathrm{hmC}$ is controlled by mechanisms other than the increased expression of IDH1 and IDH2 mRNA.

The observed abundance of $5 \mathrm{hmC}$ in adult livers and its preferential localization in actively transcribed genes suggest that bisulfite sequencing data from adult livers should be considered with caution, as bisulfite conversion does not distinguish between $5 \mathrm{mC}$ and $5 \mathrm{hmC}$ [37]. Hence, specific methods allowing discrimination between these two cytosine modifications become especially important in human liver research.

NGS of $5 \mathrm{hmC}$-enriched genomic DNA obtained from fetal and adult liver samples revealed profound differences in the genomic distribution of $5 \mathrm{hmC}$ peaks between the cohorts and significant interindividual variation among samples within the groups. Interestingly, the genomic distribution of $5 \mathrm{hmC}$ peaks did not occur at random but appeared to be dependent on the genomic context and on the stage of liver ontogeny. In general, $5 \mathrm{hmC}$ is relatively under-represented in repetitive sequences and enriched in coding regions of actively transcribed genes (Figure 5a). In addition, $5 \mathrm{hmC}$ peaks are even more enriched in CGI shores (and hence frequently overlap with CGIs), which is in agreement with the tendency of $5 \mathrm{hmC}$ to occur in regions with increased CpG density (Figure S4 in Additional file 1). These $5 \mathrm{hmC}$ distribution patterns are quite consistent with previous reports for mammalian nervous tissue and embryonic stem cells [13-17,19-21], suggesting a functional role for $5 \mathrm{hmC}$ in the regulation of gene expression. In addition, the observed tendency of $5 \mathrm{hmC}$ peaks to occur in coding genes and regions with increased CpG density may explain the over-representation of $5 \mathrm{hmC}$ blocks on chromosomes 16, 17, 19 and 22 (Figure S2 in Additional file 1). Moreover, the depletion of $5 \mathrm{hmC}$ from sex chromosomes as seen here has been observed before in human embryonic stem cells and mouse brain $[16,30]$.

We found that $5 \mathrm{hmC}$ blocks in both fetal and adult livers are strongly enriched in genes encoding miRNAs and depleted within lncRNA genes, thus suggesting a role for $5 \mathrm{hmC}$ in the regulation of the expression of miRNA genes (Figure 5a). In addition, the observation of high enrichment of $5 \mathrm{hmC}$ in hepatic enhancers suggests that $5 \mathrm{hmC}$ could play a role in the regulation of gene expression through distal regulatory elements. Moreover, our results evidently indicate the involvement of $5 \mathrm{hmC}$ in the developmental expression of proteincoding genes in human liver. Fetal-only $5 \mathrm{hmC}$ blocks (that is, genomic intervals that lose $5 \mathrm{hmC}$ during liver development, despite the increasing genomic $5 \mathrm{hmC}$ content) are especially enriched within genes annotated as belonging to developmental and differentiation-related processes, whereas in adult livers, de novo acquired $5 \mathrm{hmC}$ appears to predominantly reside in genes associated with hepatic metabolism. These data are in line with the observation of Thomson and co-authors [38], who recently described the dynamics of $5 \mathrm{hmC}$ and its effect on gene expression in mouse livers. The authors showed that following exposure to phenobarbital, rapid, dynamic and reciprocal changes in the level of $5 \mathrm{hmC}$ and $5 \mathrm{mC}$ occurred over the promotor regions of the murine genes known to be transcriptionally regulated by phenobarbital. The changes in hydroxymethylation and methylation further coincided with changes in the histone marks H3K4me2, H3K27me3 and H3K36me3, and indicate that cytosine hydroxymethylation may be crucial in the acute transcriptional regulation of specific hepatic genes.

Here we provide the evidence that adult human liver DNA contains a high level of $5 \mathrm{hmC}$. The brain is another differentiated human tissue that is highly hydroxymethylated $[14,29]$. We compared our hepatic $5 \mathrm{hmC}$ data with the available cerebellum dataset, obtained using the same chemical labeling-based method for $5 \mathrm{hmC}$ capture as in our study [30]. The results of pathway analysis of $5 \mathrm{hmC}$ intervals that are shared between cerebellum and fetal and adult human livers suggest that the presence of specific $5 \mathrm{hmC}$ signatures within genes related to sterol metabolism and insulin response could be conserved between various tissues.

\section{Conclusions}

In this study, we for the first time demonstrate that, in contrast to earlier reports, $5 \mathrm{hmC}$ is an abundant epigenetic modification in adult human liver. Our findings on the genomic distribution of $5 \mathrm{hmC}$ suggest that this epigenetic mark may be an important determinant of the expression of both protein-coding and miRNA genes in hepatocytes. Furthermore, $5 \mathrm{hmC}$ appears to play a significant role in hepatic gene expression changes during liver development. Hence, cytosine hydroxymethylation may be a missing link in the full understanding of the functional as well as the developmental processes of the liver, and also can contribute to interindividual differences in liver function and susceptibility to liver disease. Moreover, our findings suggest the importance of using 
methods that permit the discrimination between $5 \mathrm{mC}$ and $5 \mathrm{hmC}$ when investigating the liver epigenome, as the traditional methods based on bisulfite sequencing can cause erroneous conclusions.

\section{Materials and methods}

\section{Human tissues}

Liver samples from fourteen 8- to 12-week-old fetuses were acquired from Karolinska University Hospital (Huddinge, Sweden). Fifty-two liver samples originate from adult organ donors who met accidental death. Of these, 33 were acquired from Karolinska University Hospital, and 19 were commercially purchased from XenoTech (Lenexa, KS, USA) and the International Institute for the Advancement of Medicine (IIAM; Edison, NJ, USA). This work was carried out in compliance with the methods within the Helsinki declaration. The use of fetal and adult liver tissues for the purposes of this study was approved by the Regional Ethics Committee. The reference numbers for the ethical approvals by the Karolinska Institutet Internal Review Ethical Board are 2010/541-23/ 1, 2010/541-31/1, 2010/678-31/3 and 280/00.

\section{Nucleic acid purification and quantification}

DNA and total RNA were isolated from the liver samples using a AllPrep DNA/RNA/Protein Mini kit (QIAgen, Germantown, MD, USA; catalogue number 80004). DNA was quantified using a Quant-iT PicoGreen dsDNA Assay kit (Invitrogen, Carlsbad, CA, USA; catalogue number P11496) and a SpectraMax Gemini XPS/EM Fluorescence Microplate Reader (Molecular Devices, Sunnyvale, CA, USA). The RNA samples were quantified and assessed for integrity using the Agilent Bioanalyzer 2100 with RNA 6000 Nano kit (Agilent Technologies, Santa Clara, CA, USA; catalogue number 5067-1511). The RIN (RNA integrity number) values of the RNA samples used for cDNA amplification were $\geq 8$.

\section{Liquid chromatography-mass spectrometry}

In order to achieve monomers, $100 \mathrm{ng}$ of each DNA sample were treated with DNA Degradase Plus (ZymoResearch, Irvine, CA, USA; catalogue number E2020) according to the manufacturer's instructions. In parallel, 12 calibration samples containing $0.3125 \%$ to $10 \% 5 \mathrm{mC}$ and $0.0625 \%$ to $1 \% 5 \mathrm{hmC}$ were prepared from 5-Methylcytosine and 5-Hydroxymethylcytosine DNA Standard Sets (ZymoResearch, catalogue number D5405). The standards were degraded to monomers in the same manner as the DNA samples. Prepared samples were placed into the auto sampler and $5 \mu \mathrm{l}$ of samples were injected onto the LC-MS system.

Quantification of C, $5 \mathrm{mC}$ and $5 \mathrm{hmC}$ was accomplished using an Agilent UPLC 1290 system coupled to an Agilent 6460 triple quadrupole (QQQ) equipped with JetStream electrospray ionization (ESI). Chromatographic separation was performed on a Waters Atlantis T3 $(\mathrm{C} 18,3 \mu \mathrm{m}$ particles, $100 \mathrm{~mm}$ length $\times 2.1 \mathrm{~mm}$ inner diameter; Waters, Milford, MA, USA) at a flow rate of $300 \mu \mathrm{l} /$ minute and $17^{\circ} \mathrm{C}$. Mobile phase A consisted of $10 \mathrm{mM}$ ammonium acetate in MilliQ water, and mobile phase B consisted of $10 \mathrm{mM}$ ammonium formate in methanol with $0.1 \%(\mathrm{v} / \mathrm{v})$ formic acid. The initial mobile phase composition was $0 \%$ of $B$ for 10.2 minutes. From 10.2 to 13.0 minutes, mobile phase $B$ was increased to $20 \%$, and held for 1 minutes. From 14.1 minutes, mobile phase B was decreased to $0 \%$ and held until 19.0 minutes.

Mass spectrometric detection was carried out using 6460 QQQ in positive ion multiple reaction monitoring mode. The first quadrupole $(\mathrm{Q} 1)$ was set to transmit the $[\mathrm{M}+\mathrm{H}]+$ ions of the analytes and Q3 was set to transmit selected fragment ions of analytes. Multiple reaction monitoring conditions, such as dwell time, Fragment and CE, are given in Table S1 in Additional file 1. The sheath gas heater was set to $350^{\circ} \mathrm{C}$, gas flow was 5 (l/ minute) and the sheath gas flow was 10 . The instrument was controlled by Mass Hunter Workstation software (Agilent Technologies). $5 \mathrm{mC}$ and $5 \mathrm{hmC}$ contents were calculated based on the calibration curve constructed by serial standard samples (the standard samples were run twice, before and after real sample analysis). The linear fits of determined area over standard amounts ratio gave $\mathrm{R}^{2}$ values of 0.99981 for $5 \mathrm{mC}$ and 0.99941 for $5 \mathrm{hmC}$ (Figure S1 in Additional file 1).

\section{Immunohistochemistry}

Sections $(40 \mu \mathrm{m})$ of snap frozen liver were cut with a microtome cryostat (Cryo-Star HM 560M, MICROM International $\mathrm{GmbH}$, Walldorf, Germany) and fixated in $4 \%$ formaldehyde. The denaturation of sections was accomplished by treating the tissues with $1 \mathrm{M} \mathrm{HCl}$ for 30 minutes at $37^{\circ} \mathrm{C}$. Subsequently, the sections were neutralized by incubating them in $100 \mathrm{mM}$ Tris- $\mathrm{HCl}$ (pH 8.5) for 10 minutes. As primary antibodies, a rabbit polyclonal antibody to $5 \mathrm{hmC}$ (1:5,000; ActiveMotif, Carlsbad, CA, USA; catalogue number 39769) and a mouse monoclonal antibody to $5 \mathrm{mC}$ (1:500; ActiveMotif, catalogue number 39649) were used. For secondary antibodies, we used a goat antibody to rabbit Alexa 647 (1:500; Invitrogen, Carlsbad, CA, USA; catalogue number A21244) and a rabbit antibody to mouse Alexa 488 (1:500; Invitrogen, catalogue number A11059). Samples were counter-stained with the fluorescent nuclear dye 4',6-diamidino-2-phenylindole included in the ProLong ${ }^{\circledR}$ Gold Antifade Reagent mounting media (Invitrogen, catalogue number P-36931). Three-dimensional images were visualized with a Zeiss confocal microscope and ZEN 2009 software. No processing of the images was performed. 


\section{CDNA synthesis and real-time PCR}

cDNA was obtained from $1 \mu \mathrm{g}$ of each total RNA sample using Superscript III First-Strand Synthesis System (Invitrogen, catalogue number 18080-051). Real-time PCR was done with PerfeCTa SYBR Green SuperMix, Low ROX (Quanta Biosciences, Gaithersburg, MD; catalogue number 95056-500) on an ABI 7500 Fast RealTime PCR System (Applied Biosystems, Foster City, CA, USA). Relative expression values were calculated from $\mathrm{Ct}$ values using the $\Delta \Delta \mathrm{Ct}$ method. The housekeeping gene EIF2B2 was used for the normalization of expression values. Primer sequences were published before [34,39]: TET1-F, GCTATACACAGAGCTCACAG; TET1-R, GCCAAAAGAGAATGAAGCTCC; TET2-F, CTTTCCTCCCTGGAGAACAGCTC; TET2-R, TGC TGGGACTGCTGCATGACT; TET3-F, GTTCCTGGAG CATGTACTTC; TET3-R, CTTCCTCTTTGGGAT TGTCC; IDH1-F, TCCGTCACTTGGTGTGTAGG; IDH1-R, GGCTTGTGAGTGGATGGGTA; IDH2-F, TGAACTGCCAGATAATACGGG; IDH2-R, CTGACAGCCCCCACCTC; EIF2B2-F, TCAAGATTATCC GGGAGGAG; EIF2B2-R, ATGGAAGCTGAAAT CCTCGT.

\section{Gene expression profiling}

The TargetAmp ${ }^{\mathrm{TM}}$-Nano Labeling Kit for Illumina ${ }^{\circledR}$ Expression BeadChip (Epicentre Biotechnologies, Madison, WI, USA; catalogue number TAN07924) was used to amplify and biotinylate the RNA samples, according to the manufacturer's instructions. For each sample, 750 ng of biotinylated cRNA were hybridized on Illumina HumanHT-12 v4 BeadChips, according to the standard protocol. The BeadChips were scanned within $24 \mathrm{~h}$ using a HiScanSQ scanner. The raw signals were exported using the GenomeStudio software, quantile normalized and further analyzed in $\mathrm{R}$ [40].

\section{Next-generation sequencing}

Genomic DNA samples ( $3 \mu \mathrm{g}$ in $120 \mu \mathrm{l})$ were sonicated using a Covaris S2 with the following settings: duty cycle $=10 \%$, intensity $=5$, cycles per burst $=200$, time $=6$ cycles $(60 \mathrm{~s}$ each $)$, mode $=$ frequency sweeping, temperature $=4^{\circ} \mathrm{C}$. Sonicated DNA was purified with $180 \mu \mathrm{l}$ of Agencourt AMPure XP beads (Beckman-Coulter, Miami, FL, USA; catalogue number A63880) and assessed for concentration and size distribution with the DNA 1000 kit (Agilent Technologies, catalogue number 5067-1504) on an Agilent Bioanalyzer 2100. All samples manifested a size distribution between 100 and $250 \mathrm{bp}$, with peak at 150 to $200 \mathrm{bp}$.

Sheared DNA samples were enriched for the $5 \mathrm{hmC}$ containing fraction with the Hydroxymethyl Collector kit (ActiveMotif, catalogue number 55013) following the manufacturer's instructions. In parallel, non-enriched aliquots of sheared DNA were diluted 1:100. 5hmCenriched samples and their non-enriched counterparts were then ligated to TruSeq adapters and PCR amplified according to the protocol detailed in Text S1 in Additional file 1 . The resultant NGS libraries were assessed for size distribution with the DNA High Sensitivity kit (Agilent Technologies, catalogue number 5067-4626) on an Agilent Bioanalyzer 2100 and quantified using a Agilent QPCR NGS Library Quantification kit for Illumina Genome Analyzer (Agilent Technologies, catalogue number G4880A). The $5 \mathrm{hmC}$-enriched adult and fetal samples were pooled separately and sequenced on two separate lanes. The control non-enriched samples were also pooled separately for the fetal and adult samples, and each pool was sequenced on seven lanes. The flowcells (v3) were sequenced on an Illumina HiSeq2000 using paired-end sequencing of $100 \mathrm{bp}$ and $6 \mathrm{bp}$ for the index read.

\section{Sequencing data analysis}

The FASTQ sequences of all samples were aligned to the reference human genome (NCBI37/hg19) using Burrows-Wheeler Aligner (BWA) [41]. Parameter -q 20 was used for read trimming, and all reads with mapping quality $<20$ were filtered out. Duplicate reads generated during the PCR amplification were removed using SAMtool [42]. 5hmC peak identification was performed using MACS with the following parameters: tag size $=100$; effective genome size $=2.70 \mathrm{e}+09$; band width $=200$; model fold $=10,30 ; P$-value cutoff $=1.00 \mathrm{e}-05$; ranges for calculating regional lambda $=1,000 \mathrm{bp}$ and 10,000 bp [43]. The data discussed in this publication have been deposited in NCBI's Gene Expression Omnibus and are accessible through GEO Series accession number GSE49291 [44].

All subsequent steps of data analysis were done using custom Python3 scripts, which are available on request. The coordinates of genomic features were downloaded from the UCSC Table Browser (tables refGene, lincRNAsTranscripts, cpgIslandExt, rmsk, wgEncodeBroadHmmHepg2HMM). The coordinates of $5 \mathrm{hmC}$ peaks in human cerebellum were downloaded as Supplementary Data Set 10 of the original paper of Szulwach and co-authors [30] and converted to Hg19 using the Galaxy LiftOver tool [45]. The relative enrichment of $5 \mathrm{hmC}$ elements in different functional categories of genes was evaluated using the Genomic Regions Enrichment of Annotations Tool (GREAT) [46], setting the basal gene regulatory domains within $5 \mathrm{~Kb}$ upstream and $1 \mathrm{~Kb}$ downstream of the transcription start site, and up to $1 \mathrm{Mb}$ extended regulatory domains in both directions to the nearest gene's basal domain [47]. 


\section{Locus-specific validation of next-generation sequencing data}

To validate NGS data at single-base resolution in selected genomic intervals, we employed the TAB-Seq method [48]. Briefly, $1 \mu \mathrm{g}$ of DNA was oxidized with the WiseGene 5hmC TAB-Seq kit (WiseGene, Chicago, IL, USA) following the manufacturer's instructions [49]. Then, both the oxidized DNA and the corresponding untreated $500 \mathrm{ng}$ aliquots were bisulfite converted with EZ DNA Methylation-Gold kit (ZymoResearch, catalogue number D5005), and the resultant DNA samples were amplified with the following primers: DROSHA-F, TTTAGTTGGGTGGTTTTATTTG; DROSHA-R, CAACTACTTTTATACCAAC; CDH2-F, GTGGTA GTGGTTGTAATTATATA; CDH2-R, CTTAAAAAATAAATCATTCCTCCC. To increase the specificity of amplification, the first-round PCR products were purified, diluted 1:10,000 and amplified again with the nested primers: DROSHA(n)-F, GTTTTATGTTTT GTGGTAGA; DROSHA(n)-R, ACTTTTATACCAACCTAACA; CDH2(n)-F, ATGAGAAGAGTTATGATAT GGGAAT; CDH2(n)-R, AAAAATAAATCATTCCT CCC. The second-round PCR products were purified and subjected to direct Sanger sequencing (Eurofins MWG Operon, Ebersberg, Germany) [50]. The $\mathrm{C} /(\mathrm{C}+\mathrm{T})$ ratios from the oxidized samples reflect the $5 \mathrm{hmC}$ values, whereas such ratios from corresponding nonoxidized aliquots are equal to the sum of $5 \mathrm{mC}$ and $5 \mathrm{hmC}$ at the same $\mathrm{CpG}$ sites. Hence, the subtraction of the resultant $\mathrm{C} /(\mathrm{C}+\mathrm{T}$ ratios $)$ permits the calculation the $5 \mathrm{mC}$ and $5 \mathrm{hmC}$ values for each $\mathrm{CpG}$ site.

\section{Additional material}

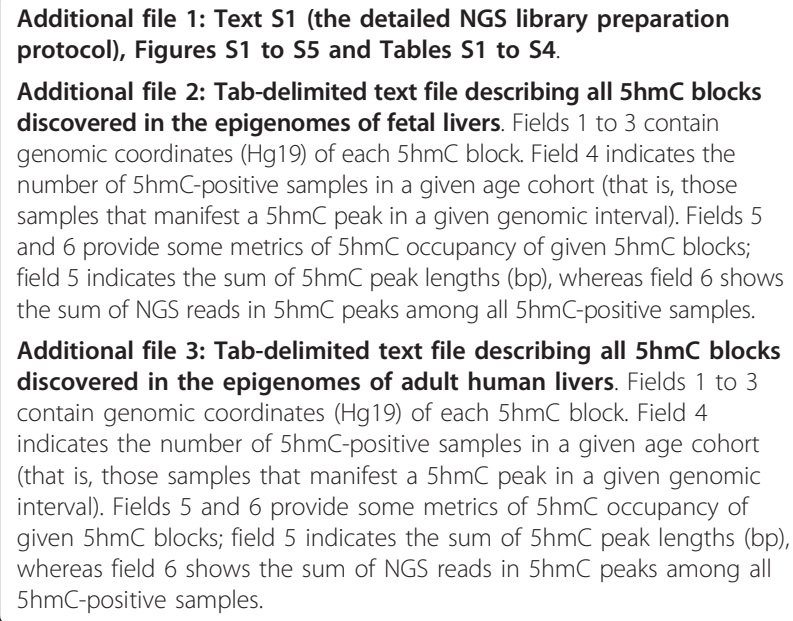

\section{Abbreviations}

5fC: 5-formylcytosine; 5mC: 5-methylcytosine; 5hmC: 5-

hydroxymethylcytosine; bp: base pair; CGI: CpG island; IDH: isocitrate dehydrogenase; LC-MS: liquid chromatography-mass spectrometry; IncRNA: long non-coding RNA; miRNA: microRNA; NGS: next-generation sequencing.

\section{Competing interests}

The authors declare that they have no competing interests.

\section{Authors' contributions}

Ml conceived the study, carried out sample preparation and data interpretation and drafted the manuscript. MKal carried out the data analysis. MKac participated in the design of the study and in sample preparation. IB carried out the immunohistochemistry assays and the locus-specific validation of NGS data. KK carried out the LC-MS analysis. AR provided the human fetal liver samples. LM carried out the next-generation sequencing and microarray assays. AM, LM and MIS participated in planning of the study and coordinated and financed the work from their grants. All authors carried out manuscript revisions. All authors read and approved the final manuscript.

\section{Acknowledgements}

The authors would like to acknowledge support from Mr Rickard Wahlström and Mr Gunnar Hägglund from Q\&Q Labs AB (Göteborg, Sweden) and Clinical Proteomics Mass Spectrometry core facility at Karolinska University Hospital and Science for Life Laboratory (Stockholm, Sweden) for providing assistance in mass spectrometry and data analysis. We also acknowledge the important help provided by Dr Lena Ekström, Dr Inger Jonasson, Dr

Chunxiao Song, Dr Chuan He, Ms Susanne Virding, Ms Heidi Martikainen, Ms Silva Kasela, Dr Paula Ann Kivistik and Mr Viljo Soo. This work is supported by grants from The Swedish Research Council, the IMI-JU project MIP-DILI (grant agreement 115336), the Seurat-1 project NOTOX, the Estonian Science Foundation (ETF9293), the European Union through the European Social Fund (MJD71) and the European Regional Development Fund, in the frame of the Centre of Excellence in Genomics; and targeted financing from the Estonian Government [SF0180142s08].

\section{Authors' details}

${ }^{1}$ Section of Pharmacogenetics, Department of Physiology and Pharmacology, Karolinska Institutet, Nanna Svartz väg 2, 17177 Stockholm, Sweden.

${ }^{2}$ Estonian Genome Center, University of Tartu, Riia 23b, 51010 Tartu, Estonia.

${ }^{3}$ Cancer Proteomics Mass Spectrometry, Department of Oncology-Pathology, Science for Life Laboratory, Karolinska Institutet Science Park,

Tomtebodavägen 23A, 17165 Solna, Sweden. ${ }^{4}$ Division of Clinical

Pharmacology, Department of Laboratory Medicine, Karolinska University Hospital at Huddinge, Medicingatan 5, 14186 Stockholm, Sweden. ${ }^{5}$ Estonian Biocentre, Riia 23b, 51010 Tartu, Estonia. ${ }^{6}$ AQ2 Institute of Molecular and Cell Biology, University of Tartu, Riia 23b, 51010 Tartu, Estonia.

Received: 24 June 2013 Revised: 30 July 2013

Accepted: 19 August 2013 Published: 19 August 2013

\section{References}

1. Ivanov M, Kacevska M, Ingelman-Sundberg M: Epigenomics and interindividual differences in drug response. Clin Pharmacol Ther 2012, 92:727-736.

2. Tahiliani M, Koh KP, Shen Y, Pastor WA, Bandukwala H, Brudno Y, Agarwal S, lyer LM, Liu DR, Aravind L, Rao A: Conversion of 5-methylcytosine to 5hydroxymethylcytosine in mammalian DNA by MLL partner TET1. Science 2009, 324:930-935

3. Kriaucionis S, Heintz N: The nuclear DNA base 5-hydroxymethylcytosine is present in Purkinje neurons and the brain. Science 2009, 324:929-930.

4. Ito S, D'Alessio AC, Taranova OV, Hong K, Sowers LC, Zhang Y: Role of Tet proteins in $5 \mathrm{mC}$ to $5 \mathrm{hmC}$ conversion, ES-cell self-renewal and inner cell mass specification. Nature 2010, 466:1129-1133.

5. Iyer LM, Tahiliani M, Rao A, Aravind L: Prediction of novel families of enzymes involved in oxidative and other complex modifications of bases in nucleic acids. Cell Cycle 2009, 8:1698-1710.

6. Reitman ZJ, Yan H: Isocitrate dehydrogenase 1 and 2 mutations in cancer: alterations at a crossroads of cellular metabolism. J Natl Cancer Inst 2010, 102:932-941.

7. Xu W, Yang H, Liu Y, Yang Y, Wang P, Kim SH, Ito S, Yang C, Xiao MT, Liu LX, Jiang WQ, Liu J, Zhang JY, Wang B, Frye S, Zhang Y, XU YH, Lei QY, Guan KL, Zhao SM, Xiong Y: Oncometabolite 2-hydroxyglutarate is a 
competitive inhibitor of alpha-ketoglutarate-dependent dioxygenases. Cancer Cell 2011, 19:17-30.

8. He YF, Li BZ, Li Z, Liu P, Wang Y, Tang Q, Ding J, Jia Y, Chen Z, Li L, Sun Y, Li X, Dai Q, Song CX, Zhang K, He C, Xu GL: Tet-mediated formation of 5carboxylcytosine and its excision by TDG in mammalian DNA. Science 2011, 333:1303-1307

9. Ito S, Shen L, Dai Q, Wu SC, Collins LB, Swenberg JA, He C, Zhang Y: Tet proteins can convert 5-methylcytosine to 5-formylcytosine and 5carboxylcytosine. Science 2011, 333:1300-1303.

10. Pfaffeneder T, Hackner B, Truss M, Munzel M, Muller M, Deiml CA, Hagemeier $C$, Carell T: The discovery of 5 -formylcytosine in embryonic stem cell DNA. Angewandte Chemie 2011, 50:7008-7012.

11. Raiber EA, Beraldi D, Ficz G, Burgess HE, Branco MR, Murat P, Oxley D, Booth MJ, Reik W, Balasubramanian S: Genome-wide distribution of 5formylcytosine in embryonic stem cells is associated with transcription and depends on thymine DNA glycosylase. Genome Biol 2012, 13:R69.

12. Song CX, Szulwach KE, Dai Q, Fu Y, Mao SQ, Lin L, Street C, Li Y, Poidevin M, Wu H, Gao J, Liu P, Li L, Xu GL, Jin P, He C: Genome-wide profiling of 5 -formylcytosine reveals its roles in epigenetic priming. Cell 2013, 153:678-691.

13. Ficz G, Branco MR, Seisenberger S, Santos F, Krueger F, Hore TA, Marques CJ, Andrews S, Reik W: Dynamic regulation of 5hydroxymethylcytosine in mouse ES cells and during differentiation. Nature 2011, 473:398-402

14. Nestor CE, Ottaviano R, Reddington J, Sproul D, Reinhardt D, Dunican D, Katz E, Dixon JM, Harrison DJ, Meehan RR: Tissue type is a major modifier of the 5-hydroxymethylcytosine content of human genes. Genome Res 2012, 22:467-477.

15. Pastor WA, Pape UJ, Huang $Y$, Henderson HR, Lister R, Ko M, McLoughlin EM, Brudno Y, Mahapatra S, Kapranov P, Tahiliani M, Daley GQ, Liu XS, Ecker JR, Milos PM, Agarwal S, Rao A: Genome-wide mapping of 5-hydroxymethylcytosine in embryonic stem cells. Nature 2011, 473:394-397.

16. Stroud H, Feng S, Morey Kinney S, Pradhan S, Jacobsen SE: 5-Hydroxymethylcytosine is associated with enhancers and gene bodies in human embryonic stem cells. Genome Biol 2011, 12:R54.

17. Song CX, Szulwach KE, Fu Y, Dai Q, Yi C, Li X, Li Y, Chen CH, Zhang W, Jian X, Wang J, Zhang L, Looney TJ, Zhang B, Godley LA, Hicks LM, Lahn BT, Jin $P$, He C: Selective chemical labeling reveals the genome-wide distribution of 5-hydroxymethylcytosine. Nat Biotechnol 2011, 29:68-72

18. Szulwach KE, Li X, Li Y, Song CX, Han JW, Kim S, Namburi S, Hermetz K, Kim JJ, Rudd MK, Yoon YS, Ren B, He C, Jin P: Integrating 5hydroxymethylcytosine into the epigenomic landscape of human embryonic stem cells. PLoS Genet 2011, 7:e1002154.

19. Williams K Christensen J. Pedersen MT, Johansen JV Cloos PA, Rappsilber J Helin K: TET1 and hydroxymethylcytosine in transcription and DNA methylation fidelity. Nature 2011, 473:343-348

20. Wu H, D'Alessio AC, Ito S, Wang Z, Cui K, Zhao K, Sun YE, Zhang Y: Genome-wide analysis of 5-hydroxymethylcytosine distribution reveals its dual function in transcriptional regulation in mouse embryonic stem cells. Genes Dev 2011, 25:679-684.

21. Xu Y, Wu F, Tan L, Kong L, Xiong L, Deng J, Barbera AJ, Zheng L, Zhang H, Huang S, Min J, Nicholson T, Chen T, Xu G, Shi Y, Zhang K, Shi YG: Genome-wide regulation of $5 \mathrm{hmC}, 5 \mathrm{mC}$, and gene expression by Tet 1 hydroxylase in mouse embryonic stem cells. Mol Cell 2011, 42:451-464.

22. Valinluck V, Tsai HH, Rogstad DK, Burdzy A, Bird A, Sowers LC: Oxidative damage to methyl-CpG sequences inhibits the binding of the methylCpG binding domain (MBD) of methyl-CpG binding protein 2 (MeCP2). Nucleic Acids Res 2004, 32:4100-4108.

23. Jin SG, Wu X, Li AX, Pfeifer GP: Genomic mapping of 5hydroxymethylcytosine in the human brain. Nucleic Acids Res 2011, 39:5015-5024.

24. Yildirim O, Li R, Hung JH, Chen PB, Dong X, Ee LS, Weng Z, Rando OJ, Fazzio TG: Mbd3/NURD complex regulates expression of 5hydroxymethylcytosine marked genes in embryonic stem cells. Cell 2011, 147:1498-1510.

25. Serandour AA, Avner S, Oger F, Bizot M, Percevault F, Lucchetti-Miganeh C, Palierne G, Gheeraert C, Barloy-Hubler F, Peron CL, Madigou T, Durand E, Froguel P, Staels B, Lefebvre P, Metivier R, Eeckhoute J, Salbert G: Dynamic hydroxymethylation of deoxyribonucleic acid marks differentiationassociated enhancers. Nucleic Acids Res 2012, 40:8255-8265.
26. Globisch D, Munzel M, Muller M, Michalakis S, Wagner M, Koch S, Bruckl T, Biel M, Carell T: Tissue distribution of 5-hydroxymethylcytosine and search for active demethylation intermediates. PloS One 2010, 5 : e15367.

27. Munzel M, Globisch D, Carell T: 5-Hydroxymethylcytosine, the sixth base of the genome. Angewandte Chemie 2011, 50:6460-6468.

28. Szwagierczak A, Bultmann S, Schmidt CS, Spada F, Leonhardt H: Sensitive enzymatic quantification of 5-hydroxymethylcytosine in genomic DNA. Nucleic Acids Res 2010, 38:e181.

29. Kraus TF, Globisch D, Wagner M, Eigenbrod S, Widmann D, Munzel M, Muller M, Pfaffeneder T, Hackner B, Feiden W, Schuller U, Carell T, Kretzschmar HA: Low values of 5-hydroxymethylcytosine ( $5 \mathrm{hmC})$, the "sixth base," are associated with anaplasia in human brain tumors. Int J Cancer 2012, 131:1577-1590.

30. Szulwach KE, Li X, Li Y, Song CX, Wu H, Dai Q, Irier H, Upadhyay AK, Gearing M, Levey Al, Vasanthakumar A, Godley LA, Chang Q, Cheng X, He C, Jin P: 5-hmC-mediated epigenetic dynamics during postnatal neurodevelopment and aging. Nat Neurosci 2011, 14:1607-1616.

31. Koh KP, Yabuuchi A, Rao S, Huang Y, Cunniff K, Nardone J, Laiho A, Tahiliani M, Sommer CA, Mostoslavsky G, Lahesmaa R, Orkin SH, Rodig SJ, Daley GQ, Rao A: Tet1 and Tet2 regulate 5-hydroxymethylcytosine production and cell lineage specification in mouse embryonic stem cells. Cell Stem Cell 2011, 8:200-213.

32. Ruzov A, Tsenkina Y, Serio A, Dudnakova T, Fletcher J, Bai Y, Chebotareva T, Pells S, Hannoun Z, Sullivan G, Chandran S, Hay DC, Bradley M, Wilmut I, De Sousa P: Lineage-specific distribution of high levels of genomic 5hydroxymethylcytosine in mammalian development. Cell Res 2011, 21:1332-1342.

33. Haffner MC, Chaux A, Meeker AK, Esopi DM, Gerber J, Pellakuru LG, Toubaji A, Argani P, lacobuzio-Donahue C, Nelson WG, Netto GJ, De Marzo AM, Yegnasubramanian S: Global 5-hydroxymethylcytosine content is significantly reduced in tissue stem/progenitor cell compartments and in human cancers. Oncotarget 2011, 2:627-637.

34. Lian CG, Xu Y, Ceol C, Wu F, Larson A, Dresser K, Xu W, Tan L, Hu Y, Zhan Q, Lee CW, Hu D, Lian BQ, Kleffel S, Yang Y, Neiswender J, Khorasani AJ, Fang R, Lezcano C, Duncan LM, Scolyer RA, Thompson JF, Kakavand H, Houvras Y, Zon LI, Mihm MC Jr, Kaiser UB, Schatton T, Woda BA, Murphy GF, et al: Loss of 5-hydroxymethylcytosine is an epigenetic hallmark of melanoma. Cell 2012, 150:1135-1146.

35. Li W, Liu M: Distribution of 5-hydroxymethylcytosine in different human tissues. J Nucleic Acids 2011, 2011:870726.

36. Hahn MA, Qiu R, Wu X, Li AX, Zhang H, Wang J, Jui J, Jin SG, Jiang Y, Pfeifer GP, Lu Q: Dynamics of 5-hydroxymethylcytosine and chromatin marks in Mammalian neurogenesis. Cell Rep 2013, 3:291-300.

37. Huang Y, Pastor WA, Shen Y, Tahiliani M, Liu DR, Rao A: The behaviour of 5-hydroxymethylcytosine in bisulfite sequencing. PloS One 2010, 5:e8888

38. Thomson JP, Lempiainen $H$, Hackett JA, Nestor CE, Muller A, Bolognani F, Oakeley EJ, Schubeler D, Terranova R, Reinhardt D, Moggs JG, Meehan RR: Non-genotoxic carcinogen exposure induces defined changes in the 5hydroxymethylome. Genome Biol 2012, 13:R93.

39. Fedrigo O, Warner LR, Pfefferle AD, Babbitt CC, Cruz-Gordillo P, Wray GA: A pipeline to determine RT-QPCR control genes for evolutionary studies: application to primate gene expression across multiple tissues. PloS One 2010, 5:e12545.

40. The R Project for Statistical Computing.. [http://www.r-project.org/].

41. Li H, Durbin R: Fast and accurate short read alignment with BurrowsWheeler transform. Bioinformatics 2009, 25:1754-1760.

42. Li H, Handsaker B, Wysoker A, Fennell T, Ruan J, Homer N, Marth G, Abecasis G, Durbin R: The Sequence Alignment/Map format and SAMtools. Bioinformatics 2009, 25:2078-2079.

43. Zhang Y, Liu T, Meyer CA, Eeckhoute J, Johnson DS, Bernstein BE, Nusbaum C, Myers RM, Brown M, Li W, Liu XS: Model-based analysis of ChIP-Seq (MACS). Genome Biol 2008, 9:R137.

44. Gene Expression Omnibus publication GSE49291.. [http://www.ncbi.nlm. nih.gov/geo/query/acc.cgi?acc=GSE49291]

45. Galaxy.. [https://main.g2.bx.psu.edu/].

46. Genomic Regions Enrichment of Annotations Tool (GREAT).. [http:// bejerano.stanford.edu/great/public/html/].

47. McLean CY, Bristor D, Hiller M, Clarke SL, Schaar BT, Lowe CB, Wenger AM, Bejerano G: GREAT improves functional interpretation of cis-regulatory regions. Nat Biotechnol 2010, 28:495-501. 
48. Yu M, Hon GC, Szulwach KE, Song CX, Zhang L, Kim A, Li X, Dai Q, Shen Y, Park B, Min JH, Jin P, Ren B, He C: Base-resolution analysis of 5hydroxymethylcytosine in the mammalian genome. Cell 2012, 149:1368-1380.

49. WiseGene.. [http://www.wisegeneusa.com/].

50. Eurofins MWG Operon.. [http://www.eurofinsgenomics.eu/].

doi:10.1186/gb-2013-14-8-r83

Cite this article as: Ivanov et al:: Ontogeny, distribution and potential roles of 5-hydroxymethylcytosine in human liver function. Genome Biology 2013 14:R83.

Submit your next manuscript to BioMed Central and take full advantage of:

- Convenient online submission

- Thorough peer review

- No space constraints or color figure charges

- Immediate publication on acceptance

- Inclusion in PubMed, CAS, Scopus and Google Scholar

- Research which is freely available for redistribution

Submit your manuscript at www.biomedcentral.com/submit 